\title{
The Cultural legacy of Music and political turmoil in Amitav Ghosh's Dancing in Cambodia at Large in Burma -A Postcolonial review
}

\author{
Dr. Venkateswarlu Yesapogu, M.A., M.Phil, PhD. \\ Head, Dept of English, Principal FAC in V.V. \&M Degree College, Ongole, Prakasam D.T., A.P, India. \\ Yvghosh.yvghosh@gmail.com
}

Abstract: Dancing in Cambodia, At Large in Burma gives a rather misleading impression to the reader who glances at its title. It seems that it is Ghosh's narrative description of his travels through these two countries after this achieved independence from colonialism. However, as one progresses along, the first impression soon gives way to a serious realization that the book defies conventional literary classification of a 'travelogue' or 'travel-writing.' In fact, it is an imaginative rendering of complex responses of a scholarly researcher and sensitive writer of the agonizing process of the evolving of a nation for two South Asian Countries Cambodia and Burma in their postcolonial phase. These responses make, no doubt, a fascinating reading have been rendered in elegant and rhythmic prose revealing the harsh realities of the political, socio-cultural, economic and ethno-regional problems that these countries were confronted with after throwing off the yokes of slavery. In sooth, these countries are still grappling with the problematic of evolution of their distinct national identities; and the writer appears to hold a mirror to the other nation-states in the region and the continent. However for my article presentation I have chosen the title called "The Cultural legacy of Music and political turmoil in Amitav Ghosh's Dancing in Cambodia at Large in Burma -A Postcolonial review, which explores the significance of Cultural legacy and political turmoil of Cambodia. This thought- provoking and disturbing book is a non-fictional personal review of the author which covered in about each and the middle - one genuinely sandwiched into historical evolution.

Keywords: Dance, Music, Legacy, Turmoil, Cambodia And Burma, Postcolonial Review. INTRODUCTION

Amitav Ghosh's nonfiction's book titled 'Dancing in Cambodia at Large in Burma' begins with an anthropological description of the sea-journey of King Sisowath along with his entourage of several dozen princes, courtiers, officials and most importantly a troupe of nearly hundred classical dancers and musicians from the royal palace at Phnom Penh. For the king, the journey that started on 10 May 1906, at two in the afternoon, aboard a French liner called Amiral-Kersaint, was the fulfilment of a lifelong dream and desire to visit France. For others it was a cherished opportunity to step out of their own land and to stage the first ever performance of Cambodian classical dance in Europe, at the exposition colonial in Marseille, an immense fairyland of an exhibition centered on the theme of France's colonial possessions. The 'colonized' situation of the dancers is sensitively portrayed in these tantalizing snippets of information of which the Marseille newspapers were often full: "it was said that the dancers entered the palace as children and spent their lives in seclusion ever after wards; that their lives revolved entirely around the royal family; that several were the king's mistresses and had even borne him children; that some of them had never stepped out of the palace grounds until this trip to France."(3)

However, Dancing in Cambodia, like other great narrative works, may be read from a variety of perspectives and thematic levels: it may be considered as the narration of a series of encounters, but also as a collection of old and contemporary travel accounts, and even as a narrative essay on the "victims of history" or as an anti-colonial manifesto. Dancing in Cambodia opens with a double encounter, fraught with consequences. It was the enthusiastic encounter 


\section{American Research Journal of English and Literature(ARJEL)}

of colonized ruler with the colonizer of his own country, during the acme of the Orientalist vogue, with the "lithe, athletic women" (Ghosh 4), whose androgynous beauty fascinated common people and even artists like "the great Rodin...into ecstasies over the little virgins of Phnom Penh, whose immaterial silhouettes he drew with infinite love, recognizing in their spontaneity the "infancy of Europe" (Ghosh 37).

Accompanying these smart dancers, as their supervisor and head, was the eldest of the King's daughters, Princess Soumphady, whose royal manners and style of dress had an electrifying effect on the Marseillais Crowd. Though she admired very enthusiastically the clothes and hats of the French women, yet she politely declined the suggestion to wear clothes like those. This was perhaps an indication of the sense of pride that she and other Cambodian women felt about their distinctive attire suited for their variety of dances. Ghosh learns the remaining story of King Sisowath and Princess Soumphady's 1906 journey to France through Chea samy, a sister-in-law of Pol Pot and a teacher at the School of Fine Arts in Phnom Penh, in 1993. The car-journey with his friend Molyka who was a mid-level Civil servant and a poised, attractive woman in her early thirties was quite a hazardous one, as it was four months before the countrywide elections to be held under the auspices of United Nation's Transitional Authority in Cambodia. The personal interview and encounter with Chea Samy reveals the latter's connection with the royal palace as also with the renowned revolutionary Pol Pot who never showed any favours to his relatives during the period of his rule. Amitav Ghosh describes the situation thus:

Chea Samy was working in a communal Kitchen at the time, cooking and washing dishes. Late that year some party workers stuck a poster on the walls of the Kitchen: they said it was a picture of their leader, Pol Pot. She knew who it was the moment she set eyes on the picture. That was how she discovered that the leader of the terrifying, inscrutable 'Organization,' Angkar, that ruled their lives, was none other than little Saloth Sar (Pol Pot) (14).

After 'breaking' of Cambodia by the Vietnamese in 1979, the country became "'like a shattered slate: before you could think of drawing lines on it, you had to find the pieces and fit them together."(16) In the post revolution period, when the ministry of culture launched an effort to locate the trained classical dancers and teachers who had survived, one of the well-known surviving dancers described their sensitive position in these words: "I was like a smoker who gives up smoking. I would dream of dance when I was alone or at night. You could get through the day because of the hard work. It was the nights that were really difficult; we would lie awake wondering who was going to be called out next. That was when I would dance, in my head."(17) As if to reinforce the significant role of culture and art in the process of national reconstruction even in the most trying circumstances, Amitav Ghosh tells the readers:

Like everyone around her, Chea Samy too had started all over again---at the age of sixty, with her health shattered by the years offamine and hard labour. Working with quiet, dogged persistence, she and a handful of other dancers and musicians slowly brought together a ragged, half-starved lunch of orphans and castaways, and with the discipline of their long, rigorous years of training they began to resurrect the art that Princess Soumphady and Luk Khun Meak had passed on to them in that long-ago world, when King Sisowath reigned. Out of the ruins around them, they began to create the means of denying Pol Pot his victory. (18)

Shifting the narrative back and forth, Ghosh highlights the problems of Cambodia's colonization by France as also the rise of Pol Pot, Khmer Rouge, other minority groups resorting to Guerrilla war-tactics, and attack by Vietnam, through the strategies of contrast and comparison. Thus the complexity of the political, social, economic, cultural and ethnic problems gets concretized with the help of analytical portrayals of Norodom Sihanouk, Minister Thiounn and his grandson Thiounn Mumm, Pol Pot and his brother Loth Sieri, King Sisowath, Son Sann, Hun Sen, Khieu Samphan, Rodin at all. In spite of all the political turmoil and chaotic-anarchic situations, one thing that kept the sprit of the 'nation' alive in Cambodia is its rich cultural heritage of music and dance. This becomes evident from the vivid description of the cultural festival that was held in Phnom Penh in 1988 amidst the destruction of social, economic, cultural and political fabric of the country: 


\begin{abstract}
But people flocked to the theatre the day the festival began. Onesta Carpene, a Catholic relief worker from Italy was one of the handful of foreigners then living in Phnom Penh. She was astonished at the response: the city was in a shambles; there was debris everywhere, spilling out of the houses on to the pavements, the streets were jammed with pillaged cars, there was no money and very little food-'I could not believe that in a situation like that people would be thinking music and dance.' But still they came pouring in, and the theatre was filled far beyond its capacity.... When the first musicians came onstage, she [a relief worker] heard sobs all around her. Then, when the dancers appeared, in their shabby, hastily made costumes, suddenly, everyone was crying; old people, young people, soldiers, children-you could have sailed out of there in a boat.'... They could not stop crying; people went through the entire length of the performance. It was a kind of rebirth: a moment when the grief of survival became indistinguishable from the joy of living. (52)
\end{abstract}

Thus, Amitav Ghosh cleverly documents the history of isolation by the Khmer Rouge and its consequences through the opening section of this book. Moreover, using examples from history, Ghosh shows that no previous regime had made such systematic and sustained attacks on the middle class. Ghosh also related Cambodia's civil war to contemporary politics. He too expresses the view that "Cambodia's was not a civil war in the same sense as Somalia's or the former Yugoslavia: it was a war on history itself, an experiment in the re-invention of society.”(10)

Conversing with people who relate anecdotes about their family history, is another device used by Ghosh to convey his impressions. It also gives the discourse, for the form of a story. For instance, Ghosh learns the story of King Sisowoth and Princess Soumphady's journey to France in 1906 through Chea Samy, a sister-in-law of Pol Pot and a teacher at the school of Fine Arts in Phnom Penh in 1993. The interview with Chea Samy reveals her connection with the royal palace and Pol Pot. And also, the French painter Rodin gives a human dimension to the unfurling of the sociopolitical history of Cambodia from May 1906 till 1993. The dates are significant, as in 1906 Sisowath and a hundred classical dancers set sail from Saigon to stage the first ever performance of Cambodian classical dance in Europe, at the exposition Coloniale in Marseille.The year 1993 is very significant as it was the year that countrywide elections were held under the auspices of the UN's Transitional Authority in Cambodia known by its acronym, UNTAC.The elections, the will-power of the people during duress and their supreme love for music and dance represent the possible resurgence and redemption of Cambodia. Amitav Ghosh cleverly shows that despite the political turmoil and prevailing anarchy, the spirit of the nation is maintained by its rich cultural legacy. This is evident from a vivid description of a cultural festival held in Phnom Penh in 1988. That's how, towards the end of the first section of his book, Amitav Ghosh shows that the passion for dance and music symbolized the politics of resurgence in Cambodia.The author sums up this mood as "a kind of rebirth: a moment when the grief of survival became indistinguishable from the joy of living."(52)

This small book is a collection of three essays previously published in journals: "Dancing in Cambodia," from Granta 44 (Summer of 1993), "Stories in Stones," from The Observer Magazine, 16 January, 1994, and "At Large in Burma," previously published in The New Yorker on 12 August, 1996. The first essay contains several illustrations by the French artist Auguste Rodin from his encounter with the dancers who are the subject of Ghosh's essay. It typifies the writer's tendency to illustrate bold historical themes through simple individual meetings.

In fact, "Dancing in Cambodia" interweaves two historical encounters. The first is the visit to Marseilles in June of 1906 of King Sisowath of Cambodia and a troupe of nearly a hundred classical dancers and musicians from the royal palace at Phnom Penh. The Second is Amitav Ghosh's visit to Cambodia in January of 1993 in search of Pol Pot's sister-in-law, who was said to be one of the country's greatest dancers- in fact, a national treasure.

Contemporary newspaper accounts suggest that the French were entranced by the exotic King and even more so by the dancers. Their emotional and curious response is perhaps a classic example of orientalisation: "For weeks now," writes Ghosh, 
The Marseilles newspapers had been full of tantalizing snippets of information: it was said that the dancers entered the palace as children and spent their lives in seclusion ever afterwards; that their lives revolved entirely around the royal family; that several were the King's mistresses and had even borne him children; that some of them had never stepped out of the palace grounds until this trip to France. (3)

In fact, whereas "they had expected perhaps a troop of heavily-veiled, voluptuous Salomes, they were not quite prepared for the lithe, athletic women they encountered.... nor indeed, was the rest of Europe" (4). Interestingly, so indescribable did they appear, so far outside the expected boundaries of categorization, that one observer later wrote that, "they seem to belong to no definite sex" (4). The visit to France by the troupe was Cambodia's contribution to the "Exposition Colonial," which celebrated France's colonial possessions. They were simply one of the many wonders that fascinated the French who took the occasion to reflect on their global empire. As Ghosh notes, "there was little by way of exotic and opulent fantasy that the exhibition did not offer, from Tunisian palaces to timber-studded West African mosques and Indo-Chinese pavilions"(2).

Ghosh goes on, however, to describe King Sisowath as a neo-colonial collaborator who sought to imitate the French, whereas the brother whom he succeeded to the throne, Norodom, had been for forty years an annoyance to the French. Sisowath's intermediary with the French was his interpreter, minister Thiounn. His grandson, Thiounn Mumm, later became immensely influential among the Cambodian elite who studied in France. Ghosh sees his complex intermediary role as "immediately recognizable to any one who has ever inhabited the turbulent limbo of the Asian or African student in Europe - that curious circumstance of social dislocation and emotional turmoil that for more than a century now has provided the site for some of the globe's most explosive political encounters" (24). Note how Ghosh sets the stage, peoples it with fascinating characters, and then rather broadly interprets the play as paradigmatic of many similar events throughout history. Among those who came under Thiounn Mumm's sway was one Saloth Sar. In 1952, Thiounn Mumm apparently inducted Saloth Sar into the French Communist party, with hideous future consequences.

\section{CONCLUSION}

As Ghosh recounts his tale of past events, he returns us to the time in which he personally enters the historical chain of events. He hopes to speak with Chea Samy because she is old enough to have known King Sisowath- and, more importantly, Princess Soumphady. Princess Soumphady had been in charge of the dancers, and in fact had been a surrogate mother for them; thus, Chea Samy would be a direct connection to the country's terpsichorean tradition. A woman named Molyka is Ghosh's friend, and it is she who will escort him to Chea Samy. Molyka is a thirty-one- yearold mid-level civil servant who had braved a great deal in her own life: in 1975, when she was thirteen, the Khmer Rouge had taken Phnom Penh and she and her extended family of fourteen people were evacuated to a labour camp in the province of kompong Thom. Three years later, ten of these were dead, including her father, two brothers, and a sister. Her mother was now a terrified woman; her brother was guilt-ridden for having accidentally betrayed their father. Understandably, Molyka was quite hesitant to meet Chea Samy, since the dancer, after all, was Pol Pot's sisterin-law.

When Chea Samy was a child, dance was one of the few means by which a commoner could gain entry into the palace. She was taken there in 1925 when she was six. When King Sisowath died two years later, his son's favourite mistress, Luk Khun Meak, who was also a dancer, brought to the palace several of her own villagers, including Chea Samy's future husband and his brother, known as Saloth Sar. He was later to be known only as Pol Pot. Because of these palace connections, Saloth Sar was given a scholarship to study electronics in Paris in 1949. While there, he was heavily influenced by several well-known leftists and communists, and upon his return three years later to Cambodia, he began working for the Indochina Communist Party. In 1963, he disappeared, and "emerged" in 1975 as Pol Pot, when the Khmer Rouge seized power. Again, notice how Ghosh weaves individual lives, often of characters whom taditional history has overlooked, into an intricate tapestry of connections. 
In 1979, the Vietnamese brought about the collapse of Pol Pots's regime, and the many evacuees began straggling back to their villages. During the intense period of his reign, however, as many as 90 per cent of the country's prerevolution artists were killed. As Ghosh puts it: "it was a war on history itself, an experiment in the re-invention of society. No regime in history had ever before made so systematic and sustained an attack on the middle class. Yet, if the experiment was proof of anything at all, it was ultimately of the indestructibility of the middle class, of its extraordinary tenacity and resilience; its capacity to preserve its forms of knowledge and expression through the most extreme kinds of adversity" (10). Why does he draw this conclusion? Since many of the survivors had to invent imaginary histories for themselves during the Pol Pot years (in order to avoid extermination), the time after wards was one of personals struggle to remember who, in fact, they were. At the same time, it was a period of reconstruction of the artistry and culture of the nation. In Ghosh's words, "they had to start from the beginning, literally, like ragpickers, piecing their familes their roofs, their lives together from the little that was left" (18). In reinventing Cambodia's culture, "they began to create the means of denying Pol Pot his Victory" (18).

Ghosh blames the French for a good bit of Pol Pot's extrems, starting with the racism the madman may have picked up from them. In any case, Ghosh describes the Khmer Rouge agenda as racist nationalism aimed at Cambodia's Vietnamese minority. He quotes the dictator's brother as believing that the troubles began when Saloth Sar (soon to become "Pol Pot") went off to Paris. The author then makes an interesting comparison between Pol Pot and King Sisowath - and broadens his observation still further. "The trip to France," he writes,

'The dream of his whole life, 'evidently cast King Sisowath's mind into the same kind of turmoil, the same tumult of shcok and bewilderment that has provoked generations of displaced students - the Gandhi's, the Senghor's, and the Kenyatta's, amongst thousands of their less illustrious countrymen - to close their doors upon the cold unfamiliarity of wintry Western cities and lock themselves into their rooms to pour their hearts out in letters, recording their impressions for those they had left at home.(39)

The émigrés he mentions are strikingly different from Saloth Sar, are they not? In fact, Pol Pot may have locked himself away in his Parisian garret and spent a lot of his time thinking and writing, but he shared very few of his thoughts with his family. His mind turned inward, towards a fundamentalist apocalyptic vision of social change. He admired the French Revolution's Robespierre, and Ghosh quotes the playwright who had that madman announce that "Terror is an emanation of virtue" (50).

King Sisowath chose the opposite path toward social transformation: rather than burning his culture to the ground, he offered an exhortation to his countrymen to imitate French techonolgy. The King's choice seems to have been the one that is now more influential in former colonies, but Ghosh, while clearly repulsed by Pol Pot, nonetheless concludes that "no one is likely to thank" Sisowath for his accommodating attitude toward the colonizer (42).

Happily, Ghosh ends his essay on an upbeat note, recording that the dance tradition that King Sisowath had brought to Marseilles and that Pol Pot had nearly succeeded in obliterating, was restored to its former glory in 1988. Chea Samy and a few others like her had managed to pass along what they knew, and in that year, classical Cambodian dance was once again performed in Phnom Penh. Thus, the storyteller shows his knack for leading us back in time, through various overgrown footpaths, demonstrating interesting forgotten incidents that ddly intersect, and then bringing us comfortably back to the spot where we began.

\section{PRIMARY SOURCES}

Ghosh, Amitav: Dancing in Cambodia, At Large in Burma. NewDelhi: Ravi Dayal, 1998. Print.

\section{Books, ARTiCles AND Reviews}

1. Almond, Ian. 'Post-Colonial Melancholy: An Examination of Sadness in Amitav Ghosh's The Shadow Lines'. Orbis Litterarum. 59.2 (2004): 99-99. Print. 


\section{American Research Journal of English and Literature(ARJEL)}

2. Anon.'Amitav Ghosh 1956: Indian Novelist, essayist and non-fiction writer; Contemporary Literary Criticism. 153 (2002): 81-132. Print

3. Ashcroft, Bill, Gareth Griffiths and Helen Tiffin's The Empire Writes- Back 1989, eds. Key concepts in PostColonian. Routledge, 1998. Print.

4. Asnani, Shyam. New Dimensions of Indian English Novel. Delhi: Doaba House, 1987. Print.

5. Barry, Peter. Biginning Theory: An introduction to literatary and Cultural theory. Manchester and New York: Manchester University Press. 1995. Print.

6. Bammer, Angelika. Displacements: Cultural Identities in Question Bloomington: Indiana UP, 1994. Print.

7. Benita, Parry. Problems in Current Theories of Colonial- theories. Oxford Literatury review of 1987. Print.

8. Bhabha, Homi. K. Nation and Narration and The location of culture. New York: Routledge. 1990, 1994. 5 March 2010. Print.

9. Bhargava, Rajul. 9ed.) Indian Writing in English: The Last Decade. New Delhi; Rawat, 2002. Print.

10. Bhatt, Indira and Indira Nityanandam. (eds.) The fiction of Amitav Ghosh New Delhi: Creative Books, 2001. Print.

11. Boehemer, Ellike. Colonial and Postcolonial literature: My grant Metaphores. Londaon: Oxford Press, 1995. Print.

12. Bose, Brinda. (ed.) Amitav Ghosh: Critical Perspectives. Delhi: Pencraft International, 2003.Print.

13. 'Footnoting History: The Diasporic Imagination of Amitav Ghosh' in Makarand Paranjape (ed) In Diaspora: $235-45$.

14. Carr, E.H. What is History? U.K. Penguin Books 1973-55. Print.

15. Chakravorty, Gayatri Spivak. In Other Worlds: Essays in Cultural Politics. London: Routledge, 1988. Print.

16. Chambers, Claire. The Relationship between Knowledge and Power in the Work of Amitav Ghosh Leeds, 2003. Print.

17. Champeon, Kenneth. 'The Last Queen of Burma'. The Iriwaddy. I July < http://www.irrawaddy.org.> 2003. Print.

18. Chatterjee, P. The National and its Fragments: Colonial and Post-Colonial histories. Princeton: Princeton University Press 1993. Print.

19. 'Nationalist thought and colonial world: London Press 1986. Print.

20. Chatterjee, Roma. 'Between Myth and Ethnography: An Anthropology Reading of In An Antique Land; in Brinda Bose (ed.) Amitav Ghosh: 91-102.

21. Clifford, James. 'Looking for Bomma' London Review of Books. (24 March 1994): 26-27. Print.

22. 'The Transit Lounge of Culture'. Times Literary Supplement (3 May 1991): 7-8. Print.

23. 'Dancing in Cambodia, At Large in Burma'. India Star Review of Books. http://www.indiastar.com/ mukherjeei. html 1998. Print.

24. Dhawan, R.K. (ed.) The Novels of Amitav Ghosh New Delhi: Prestige, 1999. and 2010. Print.

25. Dhondy, Farrukh. Bombay Duck 1990; 24. Print.

26. Dixon, Robert. 'Travelling in the west: The Writing of Amitav Ghosh'. The Journal of Commonwealth Literature. 31.1 (1996):3-24. Print.

27. 'Footnoting History; The Diasporic Imagination of Amitav Ghosh in Markar and Paranjape(ed) In Diaspora: 235-45. 
28. Graff, Gerald. 'Cultural Criticism Redrawing the Boundaries, ed Stephen Greenblatt and Giles Gunn. 1996: 421. Print.

29. James, Louis and Jan Shepherd. 'Shadow Lines: Cross Cultural Perspectives in the Fiction of Amitav Ghosh'. Common Wealth Essays and Studies.14. 1 (1991):28-32.Print.

30. Jameson, Frederic. 1991. 'Post Modernism or the Cultural Logic of late Capitalism. London: Verso. 2000. Print.

31. 'The Political Unconscious: Narrative as a Socially Symbolic Act'. London and New York: Routledge, 2002 (1983). Print.

32. 'The Politics of Isolation and Resurgence in Dancing in Cambodia, At Large in Burma' in R.K.Dhawan (ed.) The Novels of Amitav Ghosh: 282-94. 2001. Print.

33. Mc Leod, John. Beginning Post-Colonialism: Manchester: Manachester University Press 2000. Print.

34. 'Dancing in Cambodia, At Large in Burma'. India Star Review of Books. 1998. http://www.indiastar.com/ mukherjee1.htmL

35. Peterson, Kirsten Holst. And Anna Rutherford: 'Double colonization' in A Double Colonization, Colonial and Post-Colonial Women's Writing. 1986. Print.

36. Reddy, Sheela. 'Writing Through Turmoil'. Outlook, New Delhi, 19 August 2002. Print.

37. 'The Politics of Isolation and Resurgence in Dancing in Cambodia, at Large in Burma' in R.K.Dhawan (ed.) The Novels of Amitav Ghosh: 282-94.

38. Tripathi, salil. 'The Past is Now: Review of Dancing in Cambodia, At Large in Barma'. Far Eastern Economic Review. 61.31 (30 July 1998): 42-43. Print.

39. Young, Robert J.C. Postcolonialism: A Very Short Introduction New York: Oxford UP, 2003. Print.

40. Zinkin, Taya. 'Review of Dancing in Cambodia, At Large in Burma'. Asian Affairs. 30.2 (1999): 230-31. Print.

41. 'Dancing in Cambodia'. Granta: The Last Place on Earth. 44 (1993): 125-69. Print.

42. 'The Diaspora in Indian Culture'. Public Culture. 2.1 (1989): 73-78. Print.

\section{AUTHOR's BIOGRAPHY}

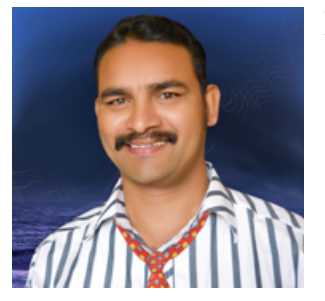

Dr. Venkateswarlu Yesapogu awarded his PhD degree in the contemporary Indian fiction at the Acharya Nagarjuna University, GUNTUR, Andhra Pradesh, India, his M.A., M.Phil, also happened in the English literature. He is now teaching English Literature and Phonetics in V.V. \&M. Degree College. He became the youngest Principal FAC by virtue of seniority among existing staff since 2009. His teaching is on main research interests including teaching of Phonetic Science as well as communication skills. He has recently published two books. The first entitled "The Fictional World of Amitav Ghosh" with ISBN 9789382186397; the second entitled "The Feminist Perspective in Amitav Ghosh's Oeuvre" and published several other articles in reputed international journals. He has participated National and International seminars/ conferences

Citation: Dr. Venkateswarlu Yesapogu, The Cultural legacy of Music and political turmoil in Amitav Ghosh's Dancing in Cambodia at Large in Burma -A Postcolonial review American Research Journal of English and Literature Volume 2016; pp:1-7

Copyright (C) 2016 Dr. Venkateswarlu Yesapogu This is an open access article distributed under the Creative Commons Attribution License, which permits unrestricted use, distribution, and reproduction in any medium, provided the original work is properly cited. 